УДК 327(4-672):623.454.8

\author{
Mariia Kurando \\ Foreign Affairs Analyst, Master of Arts in International Relations \\ $\mathrm{PhD}$ student \\ Department of International Relations, \\ Odesa I. I. Mechnikov National University \\ French Blvd., 24/26, Odessa, Ukraine \\ Tel.: +30482633259 \\ E-mail: kurando.maria@gmail.com \\ ORCID: https://orc.idorg/0000-0002-1272-2954 \\ DOI: http://dx.doi.org/10.18524/2707-5206.2021.34.229954

\section{Teona Patussi} \\ Master's Student at Dublin City University (Ireland) under IMSISS programme, \\ Dublin City University (Ireland), \\ Collins Ave Ext, Whitehall, Dublin 9, Ireland \\ Tel.: +447548616070 \\ E-mail: teona.patussi2@mail.dcu.ie \\ DOI: http://dx.doi.org/10.18524/2707-5206.2021.34.229954
}

\title{
ENHANCING EUROPEAN SECURITY: MODERN CHALLENGES POSED BY NUCLEAR WEAPONS
}

The proposal of Europeanising French deterrence was revived by French President Emmanuel Macron, who declared in February 2020 that French nuclear forces reinforce European security simply by existing and suggested a strategic dialogue with all EU partners regarding the role of French nuclear weapons in European security. Macron further reasoned that this issue is increasingly urgent nowadays as the EU must jointly realise that, because of the lack of a legal structure, they may easily find themselves vulnerable to the resumption of a traditional, even nuclear, arms race on their land. The prospects of global control of weapons and disarmament efforts are very blurry in the times of rising political tensions, revived nuclear arms races, and weakening trust in multilateralism. Nevertheless, this all leads to the necessity to support active actions towards nuclear risk reductions, whichhave recently appeared in some of the multilateral forums. The elimination of nuclear risk is nothing but an intermediate measure to reduce nuclear proliferation dangers until they are liquidated. It is essential to review the risks of accidents involving nuclear weapons and their influence on European security, along with focusing on the role of European nuclear weapon states (NWS), their place in global security and possible scenarios for their future: the authors considered the possible prospects of the EU as another entity with nuclear weapons, as well as the likelihood of the EU as another regional nuclear-free zone and discussed whether the real change is possible.

Key words: nuclear weapons, European security, non-proliferation, the EU, nuclear risks reduction, NPT, NATO.

\section{Introduction}

Over the years, the international balance of power and the structure of government institutions, foreign policy approaches and political personalities 
have changed. The role of a nuclear weapon in global security is the only thing which remains constant. Just like accessibility to capital by way of resources influences the position of people and their opportunities, the possession of nuclear weapons defines the state's place in the world order.

The prospects of global control of weapons and disarmament efforts are very blurry in the times of rising political tensions, revived nuclear arms races, and weakening trust in multilateralism. Nevertheless, increasingly strong support for what is frequently termed 'nuclear risk reductions' has recently appeared in some of the multilateral forums, i.e. policies that contribute towards reducing risks of nuclear weapons being used, either accidentally or on purpose. The elimination of nuclear risk is nothing but an intermediate measure to reduce nuclear proliferation dangers until they are liquidated.

For the first time in more than two decades, a serious debate on the role of nuclear weapons in European security has resurfaced in Europe. Such discourse has been fuelled by strategic and political developments: the entrance into a new stage of international relations, characterized by a return to the logic of power between the major strategic actors and deterioration of security structures.

It is clear that nuclear deterrence has always been a crucial component of ensuring peace and strategic stability in Europe. However, the EU is under the fear that a strategic rivalry between the US, Russia, and China could occur at their cost. EU states ought not to be witnesses or bystanders to strategic developments that directly affect them all. In these pivotal years for Europe, reclaiming the strategic debate by Europeans is thus crucial.

Nuclear weapons pose a great threat to the global security and thus, to Europe as a major part of the world. The main advantage of discussing topic of nuclear risks reduction and possible ways of action for Europe is the opportunity to avoid focusing on controversial and politically-polarized questions such as the value of nuclear weapons from the military perspective, for instance. Moreover, the article is not aimed at discussing the positive and negative effects of deterrence and question its effectiveness, as well as calling for disarmament scenarios.

It is essential to review the risks of accidents involving nuclear weapons and their influence on European security, along with focusing on the role of European nuclear weapon states (NWS), their place in global security and possible scenarios for their future: would the EU become yet another nucleararmed entity, or would it become another regional nuclear-free zone, and would anything change?

\section{Risks of accidents involving nuclear weapon}

The essence of the security topics is hard to overestimate, especially when they are discussed in terms of nuclear weapons. In the focus of the article there are several groups of risks, that rise concern in the context of European and global security: the ones connected to technical failures (false alarms, technical malfunction, and human failure), the ones involving criminal activity (cyberattacks, possibilities of unauthorized action, nuclear materials traf- 
ficking and terrorist attacks), and general risks (the lack of sufficient legal base and tension in relations between nuclear weapon states).

The risks connected to technical failures are discussed frequently in recent years, especially after the report of the Global Zero Commission on Nuclear Risk Reduction called 'De-Alerting and Stabilizing the World's Nuclear Force Postures', which was presented at the 2015 NPT Review Conference. Moreover, the topic raises concern also because such scenario is likely to happen and there are real examples of false alarms that could lead to devastating consequences.

More than forty years ago, on November 9, 1979, at 3 am Zbigniew Brzezinski, a National Security Advisor, received a phone call claiming that the NORAD (North American Aerospace Defense Command) early-warning systems detected an imminent nuclear attack on the United States. It was reported that 2,200 missiles were launched from the territory of the Soviet Union. Fortunately, it was soon revealed that the NORAD message was a false alarm caused by software. This incident was one of the most dangerous false alarms, but it was neither the first nor the last one (Kimball, 2019).

Another well-known incident happened in the Soviet Union in 1983. Lieutenant Colonel Stanislav Petrov without any exaggeration can be called "the Man who saved the world" and it is not a coincidence. He was the officer in charge the night of September 26, when a Soviet early-warning system detected that the US had launched an attack on the Soviet Union. He was the one who had to make a choice: to report an attack or to refuse pass the alert to Moscow. He doubted that the US could start the war with only five missiles and reported a false alarm, which saved the world (Lewis et alia, 2014, p.13).

These false alarms are not all the historical examples, but the most prominent ones. Most importantly, these incidents successfully illustrate the dangers posed by nuclear weapon existence to the global security at our times. Russia and the US deploy a great number of nuclear warheads (approx. 1,600 for Russia and 1,800 for the US) (Kristensen \& Korda, 2021) on hundreds of sea and land-based missiles and long-range bombers, which is more than needed to deter the opponent and more than enough to lead to devastating consequences in case of nuclear exchange, including the one triggered by false alarm.

It also should be taken into consideration that the above-mentioned cases of false alarms illustrate the example of possible unintended useof nuclear weapon, when the catastrophe could happen due to a technical error. Another scenario, which was quite in a spirit of Cold War times, was the possibility of intended use of nuclear weapon based on incorrect assumptions, when the strike was authorized based upon, what would be learned later, incorrect information, misperception or misunderstanding. However, one of the modern security challenges includes the risk of unauthorized use of nuclear weapons as the result of cyberattacks and other criminal activities.

For instance, in July 2018, President Vladimir Putin claimed that during the 2018 World Cup in Russia almost 25 million cyberattacks and other attempts of a criminal character on Russia's information infrastructure 
were neutralized (Cerulus, 2018). Such number of cyberattacks over a several weeks is frightening, however, it is even more concerning considering the fact that they were conducted against Russia, one of the countries with largest deployed nuclear arsenal. It is also worrisome because of the possibility of launching nuclear strike due to technical or human failure, when trying to respond to the false indications of an attack, triggered by criminal activities such as terrorist or cyber-attack.

Another issue is connected to nuclear trafficking and has its special place in European affairs due to the number of contested spaces, which pose the major threats due to the lack or absence of clarity on the situation. It is problematic due to the following reasons: firstly, it is complicated to understand the scale of nuclear security threats, and secondly, due to the failure to gain legitimate governmental control over these spaces, it makes them safe havens for smugglers. Moreover, such territories serve not only as perfect places to store or hide nuclear materials, but they can be a source of these materials. Thus, for instance, 2 kilograms of HEU had gone missing in 1997 from the the Ilia Vekua Sukhumi Institute of Physics and Technology in Abkhazia, as well as 7 kilograms of other nuclear material, according to the IAEA (Galeotti, 2007, p. 60).

Also, in context of nuclear trafficking it is important to mention thecase of Ukraine. Not only are the DonetskPeople's Republic (DPR) and the Luhansk People's Republic (LPR) together the largest contested space in the Black Sea region, but they also represent the space with the highest volume of radioactive materials. Thus, the main security concern here is the possibility of illegal trafficking of radioactive materials and waste from the territory beyond Ukrainian control. It is claimed that such actions can result in contamination of the environment and public exposure due to unsealing of radiation sources, and the possibility of using them as a 'dirty bomb' (Fedchenko and Anthony, 2018:19).

In the context of the third group of risks it is crucial to discuss the effectiveness of legal base in terms of dealing with modern security challenges. In the article the topic of terrorists using the nuclear weapon was stressed a lot. The reason for that is that the possibility of nuclear war breaking out intentionally by NWS leader is quite blurry, but the same is hardly could be said about terrorists, who could acquire nuclear weapon. Other above-mentioned security threats were described in the same manner: they are real and may happen more likely than large-scale nuclear war. Thus, it is important to discuss what international treaties or agreement are aimed at nuclear risk reduction. For the purpose of the article it is particularly important to view the Non-Proliferation Treaty (NPT) as the main tool for regulating nuclear weapon affairs.

The main goal of the NPT is to prevent non-nuclear states (NNS) from possessing nuclear weapon and limit the number of nuclear weapon states (NWS) to five, with a long-term aim to eliminate nuclear weapons (International Atomic Energy Agency, 1970). One of the main problems with the NPT is that it has not changed over time and adapt to modern state of affairs. The diplo- 
macy and dialogue between states becomes the main tool for such relations. Ideally, the world community has to strive for non-proliferation regime and the peaceful world order has to be in their interests. However, such scenario is hardly possible, considering the geopolitical situation and the role and importance of nuclear weapon in modern world.

Despite the goals and aims of NPT, there are countries like North Korea and Iran that continue pursuing programs for nuclear weapon capabilities. In such cases as this, there is a certain possibility of terrorist acquiring nuclear materials or even nuclear weapon, as, unfortunately, there is no real restraining impact on these states (Martin, 2016).

Thus, if we bring up such topic as nuclear terrorism, we can say that abstention of NPT members from producing new nuclear weapons helps stop terrorist from acquiring nuclear weapons and materials, and has proven to be successful. However, the possibility of North Korea, for instance, selling excess nuclear devices is of a particular concern (Snyder, 2015).

The NPT does not address terrorist organizations or non-state actors much, it is mostly focused on NNS and the role of NWS, which includes banning NNS from acquiring prohibited nuclear materials. It also somewhat emphasizes the loose obligation to share technology to NNS, which is also concerning considering the interest of some NNS in nuclear weapons (Martin, 2016, p. 18).

NNS in their turn claimed not to conduct prohibited testing or research, however, NNS may choose to withdraw from treaty (International Atomic Energy Agency, 1970). Considering the pressure from the world community that would follow such a choice and the assurances taken by NWS to ensure NNS being nuclear weapons free, the withdrawal from treaty is hardly to happen. The same cannot be said about terrorists and non-state actors, which simply do not have any assurances and agreements (Martin, 2016).

Thus, the world faces another security threat and existing treaties, protocols and agreements do not meet it. Moreover, the legal base regulating nuclear weapon affairs seem to be even more insufficient considering the present arms control agreements.

In essence arms control was a product of the world order existing during the Cold War. Understanding of the devastating nature and real danger of the nuclear weapon led to the series of agreements (including the Partial Test Ban Treaty, the NPT, the Strategic Arms Limitation Talks that lead to further weapons control agreements, the INF Treaty and so on). That time the international politics was based on and determined by the confrontation and competition of two superpowers, so the only logical way of promoting international security was the limitation and reduction of nuclear weapons by achieving strategic parity, therefore creating guarantees for the absence of nuclear war.

Right now, the situation is quite different: the relations between the USA and Russia are not central in the international arena anymore, however, are getting more and more important in terms of arms control. The only legallybinding document left is New START, and it is argued whether its content is 
in line with the spirit of time. Such state of affairs is probably the greatest danger for Europe, as the consequences of US-Russian tensions are also vivid, the same as the possibility of nuclear war due to the false alarm, or terrorist attack.

For years the United States has been the ally of Europe and has established the so-called 'nuclear umbrella' over their territory for protection, and it is not a coincidence that major European security concern is connected to the American presence on European soil. Keeping in mind that after the collapse of the Intermediate-Range Nuclear Forces Treaty (INF Treaty) the European security is at stake, American nuclear umbrella seems to "attract" the potential enemy's missiles more than repel them. It is also specifically important to mention that in case of the US, the number of deployed nuclear warheads includes the non-strategic nuclear weapons (NSNWs) in Europe at six bases in five countries (Belgium, Germany, Italy, Netherlands and Turkey) (Credi, 2019).

There are several issues connected to the American NSNWs in Europe. Firstly, the facilities hosting US NSNWs are not necessarily safe, at least as one might desire. There were some incidents, including the protests on the KleineBrogel Air Base (Belgium) in 2010, when activists were able to bypass the authorities, both American and Belgian, who were responsible for the security of the base (Kristensen, 2010). There were certain concerns about the Incirlik Air Base, particularly the possibility of ISIS terrorist attempt to attack the facility, and even more anxiety about the base's security appeared after the 2016 attempted coup d'état (Nuclear Threat Initiative, 2016).

However, talking about terrorist attacks, European facilities hosting US NSNWs could hardly be at such risks. The reason for that is the difficulty of conducting such operation by terrorist groups, as to acquire the weapon they would have to access the facility, steal the bomb and find a way to transport it. Under such circumstances the success of the operation is quite controversial, which makes the risk of terrorist attack on these facilities unlikely (Credi, 2019).

However, there are other reasons for security concerns. For instance, because of the geographical closeness to Russia's NSNWs the Baltic states and Poland feel unsafe in the face of possibility of Russian nuclear aggression, in case of bringing the potential conflict to nuclear level.

\section{The future role of the non-American nuclear weapons in the EU}

For more than 50 years, the concept of a European nuclear deterrence has been a frequent element in the continent's security discussion, and often referred to as an 'elephant in the room.' (Tertais, 2019)

There were proposals for a nuclear multilateral force under European influence in the early 1960s, as Europe demanded more leverage in North Atlantic Treaty Organization (NATO) strategy, although numerous states voiced doubts regarding the prospect that the upcoming Nuclear Non-proliferation Treaty (NPT) would retain a European nuclear option. Overall, the discourse is centred on two arguments. One is that the dependability of the United 
States' nuclear assurance to NATO allies on the continent can not be taken for granted. U. S. offers a nuclear umbrella to Europe by nuclear "stationing" (U. S. bombs are stationed in Europe) and nuclear "sharing" (many European air forces are equipped to bear those bombs in wartime) in NATO. The second point, is that the EU should be more independent from the U. S. and establish its own security identity (Tertrais, 2019)

Nuclear deterrence has always been a crucial component of ensuring peace and strategic stability in Europe. There are two distinct components to this deterrence: U. S. acting through NATO and Europe's own nuclear powers, France and the United Kingdom. According to Jurgensen (2019). the concept of a European nuclear deterrent as such did not arise until the 1950s in Western Europe, as a result of a lack of trust in U. S. security assurances after the 1956 Suez Crisis. Therefore, as Europe became concerned that Washington would fail to engage its strategic arsenal on European Economic Community territory, proposals for a European atomic pool began to surface, enabling Europe to minimise its strategic dependency on the U. S.

The concept of implementing European nuclear powers arose mainly after the Cold War ended, as the strategic transition triggered by the dissolution of the Warsaw Pact had a major effect on the continent's nuclear environment (Egeland \& Pelopidas, 2020). The most significant option was then considered: "concerted deterrence", which implied expanding the French nuclear umbrella to the rest of the European Union. Yet, these numerous efforts failed because the threat of decoupling between Western Europe and the United States was too high for some European countries. As a result, nuclear deterrence in Europe has been dominated by the American nuclear umbrella and NATO. Nonetheless, with Donald Trump's latest remarks on NATO and the United States' diplomatic pivot to Asia, the European Union's stability might no longer be assured by its American ally (Hille et al., 2020). The future of European nuclear capabilities is, therefore, being called into question, as is the debate over the establishment of a proper European nuclear deterrent based on the continent's two nuclear arsenals (Quintin, 2020).

Hincu (2015) asserts that in the area of nuclear non-proliferation, the EU is far from being a unified actor. Before the EU may act on a proliferation issue, it must first reach an internal agreement. The difference in nuclear statuses within the Union, as well as different attitudes toward the transatlantic bond, are the two major constraints to EU action on nuclear non-proliferation.

The EU's gradual acquisition of a position in non-proliferation during the 1990s took place in an atmosphere in which NATO's centrality was frequently questioned. The Union's alliance with the United States remained critical. In security matters, nevertheless, Member States presented contrasting levels of willingness to express disagreements with U. S. strategies. NATO's members, who make up the majority of EU states, were concerned that antagonizing the US over nuclear issues would have eroded the Alliance's security relationship. Larose (2000), in fact, strongly argues that every European country's stance toward nuclear weapons is heavily affected by its alliance with NATO. Aside from these obstacles, the fact that non-proliferation has been a non-issue in 
European political debate has undoubtedly hampered the development of an EU position in the field.

Portela (2003) highlights that due to the virtual absence of a public discussion on nuclear weapons over the last decade, European governments have faced little pressure from civil society to improve their position in non-proliferation. Undoubtedly, the EU's Member States' conflicting views toward nuclear weapons make it very hard for the EU to find consensus on a series of matters. The author also points out that the EU's non-proliferation initiatives have been motivated by nothing resembling a long-term policy. Instead, the Union's goals have been middle-term in nature and they can be found somewhere in between the maintenance of the nuclear status quo and the farreaching initiatives of disarmament-minded nations.

\section{Scenarios for the future}

The worsening of the EU's security and strategic context may explain the revived nuclear debate. Russia's aggressiveness, as shown by the Ukraine crisis in 2014, reintroduced the prospect of a major European crisis as it prompted a renewed European interest on the means to ensure their existence and territorial sovereignty (Jungensen, 2019). This is especially true not just for those nations that joined NATO at the turn of the century e.g., Baltic States and Poland, but also EU member states which are not part of NATO for instance Sweden and Finland and therefore do not depend on an official U. S. guarantee but are concerned about Russia.

Moreover, Donald Trump's election as president in 2016 raised questions about U. S. integrity with prolonged promises to nuclear deterrence (Kimball\&Reif, 2017). The rise of conflicts among military powers, a proliferation of the regional security crises and deteriorated international arms control also highlighted the new global concerns. Furthermore, the future of United States-Russia strategic cooperation has abruptly come into question as in 2018 the United States withdrew from the EU-brokered Iran nuclear deal and the Intermediate-Range Nuclear Forces Treaty (INF) in 2019, because of the imminent absence of the global arms control agreement for this type of weapons.

Noteworthy, Waltz (1981) argues that over the last decade a general perception has emerged that nuclear weapons are gaining in importance as global power tools (for instance North Korea), prompting the political as well as the public opinion to argue that the EU should strive toward a common nuclear deterrent. Whereas France was at the forefront of this discussion in the 1990s, today's conceptual impetus is from Germany, with its notion of concerted deterrence. Since these last few years, numerously different scenarios have been foreseen: first, an enhanced position for French and British strategic nuclear forces; secondly, French extended deterrence employing French nuclear weapons in other EU states; thirdly, the 'Europeanisation' of French deterrence under a joint European command, with joint funding and ideology and, lastly, the implementation of German nuclear deterrent. All this, according to Quintin (2020) could result in a strengthening of Europe's strategic stability. 
Blanc (2018) suggests that the German-Franco axis could be a good contender to take on the heavy burden that NATO currently bears. The author further adds that nuclear deterrent concerns must be widely discussed since they are crucial to Europe's future and mutual defence. Under certain circumstances, the concept of European nuclear deterrence could offer real diplomatic influence for a European nuclear de-escalation strategy.

The proposal of Europeanising French deterrence was revived by French President Emmanuel Macron (2020), who declared in February 2020 that French nuclear forces reinforce European security simply by existing and suggested a strategic dialogue with all EU partners regarding the role of French nuclear weapons in European security. Macron (2020) further reasoned that this issue is increasingly urgent nowadays as the EU must jointly realise that, because of the lack of a legal structure, they may easily find themselves vulnerable to the resumption of a traditional, even nuclear, arms race on their land.

Critics, including Credi (2019), strongly argue that such a strategy is flawed. First, neither the United Kingdom nor France has shown real readiness to expand their deterrent capabilities beyond state boundaries, according to Thränert (2017). Second, even if that was the case, the joint nuclear arsenals of the United Kingdom and France are little more than 500 nuclear weapons, of which only 400 are deployed, this would not be an equitable deterrent against Russia. Besides, the United Kingdom's arsenal is exclusively submarine-based, with four Vanguard-class ballistic missile submarines (SSBN) (Nuclear Threat Initiative, 2015). Given the European allies' restricted territorial waters, deploying a submarine as a direct substitute for U. S. NonStrategic Nuclear Weapons (NSNW) would expose its position, undermining the aim of a nuclear-armed submarine (Credi, 2019).

Others have suggested a different approach: the United Kingdom and France might contribute some of their current nuclear weapons, while Germany will finance the development of new ones (Wimmer, 2018). However, such strategy is blatantly in violation of the Treaty on the Non-Proliferation of Nuclear Weapons (NPT). The development of new nuclear weapons contradicts the very idea of non-proliferation and is likely to undermine the NPT's remaining legitimacy. A similar extension will, in every sense, reflect a European nuclear weapons program (Credi, 2019).

Credi (2019) concludes that the establishment of a Eurodeterrent is inadequate as an alternative to American NSNWs in Europe. That is not to say that a nation's deterrence should be a static strategy. Deterrence must "evolve" over time. (Cappello et al.,2002) However, NATO cannot fail to provide an adequate level of protection to its members by leaving Europe without an effective deterrent or by pursuing a proliferation strategy (Credi, 2019).

A new nuclear arms race will be the most alarming and, also the most likely scenario following the full elimination of American NSNWs from the European soil. The main drivers of proliferation decisions are, indeed, security concerns (Sechser, 2016). The prospect of Washington removing its NSNWs has prompted many European countries to consider developing their 
own nuclear stockpile. In Germany, a number of opponents and researchers claimed that the country requires nuclear weapons, and consequently they believe that the NPT should be abandoned. Failure to do so, they claim, would expose the nation to potential Russian aggression (Terhalle, 2017). Withdrawing from the NPT is not illegal. However, it would certainly result in a complete collapse of the NPT, and the increase of many new nuclear nations, a critical scenario if all or even several European nations want to pull out the Treaty. Sechser (2016) highlights that a nation that hosts an ally's nuclear weapons is less likely to feel the need to defend itself by creating its own nuclear arsenal.

Similarly, Perry et al., (2009) point out that if Washington retains its NSNWs in Europe, its partners in the rest of the world would have no incentive to create their own nuclear arms. The nuclear turmoil triggered by the recent U. S. Nuclear Forces Treaty pull-out and its reluctance to expand New START has led the world to face further nuclear proliferation threats. With the INF in turmoil, the ability to access existing nuclear weapons provides the U. S. with a level of flexibility that would be lost if NSNWs were withdrawn from Europe.

It is unquestionably advantageous to rely on these weapons rather than potentially creating new ones. Those who argue that enhanced deterrence is not an effective strategy for conflict avoidance, intensify the threat of nuclear proliferation. These opponents, according to Doug (2018) are unwittingly urging NATO's European allies to build their own nuclear arsenal. Deterrence, on the other hand, has not failed since the invention of nuclear weapons. Although it is difficult to prove that Washington's extended deterrence policy was responsible for avoiding a European nuclear arms race during the Cold War, an effective deterrence strategy is evident in the lack of war between nuclear-armed or umbrella-protected nations (Credi, 2019).

Jurgensen (2019) indicates that EU states must build initiatives that will enable them to be trustworthy allies or to function more independently when and if required. The deterioration of Europe's security architecture must prompt European Union to undertake an in-depth analysis of the continent's strategic stability conditions. Priority should be given to defining their own security interests and specific arms control initiatives consistent with those interests (primarily to reduce mutual mistrust, strengthen accountability on doctrines and capacities, and reduce the risks of unintentional or unregulated escalation) (Bustlein, 2018).

Muller et al., (2016), strongly criticizes the concept of Eurobomb, in particular, because France might be soon the only nuclear-armed state left in Western Europe. In that case, the pressure to create a European nuclearweapon-free zone could gain weight.

In conclusion, whether the European Union or individual member states will become another nuclear-armed polity or a nuclear-weapon-free zone, or whether nothing will alter, hinges on whether those who see nuclear weapons as "powerful" and legitimate or those who see them as too dangerous and unconstitutional, will prevail in the coming social and political discourse. It 
is clear that the question must be addressed at some point in time, as the EU moves toward greater security integration.

However, it is important to note that a substantial discussion of nuclear disarmament is extremely complex because of the composition of the European Union, which currently comprises many non-NATO nations, several of them with a long history of neutrality or in favour of disarmament (Cottey, 2014). As a result, the concept of a "Eurodeterrent" appears to be stuck in a paradoxical situation, caught between a deteriorating EU security context and a prohibitionist ideology backed by the majority of EU states (Quintin, 2020).

Yet, according to Tertais (2019), there are no grounds to assume that this discussion in the near future would lead to some form of "European bombs." An enduring sense of insecurity and confusion about the future of the security guarantee in the US can, however, encourage a new debate among European countries concerned on nuclear deterrence and can contribute to a stronger French position in safeguarding the safety of its partners.

\section{Conclusions}

The role of nuclear weapons in global security is hard to overestimate. For many years, global trends and policies have been shaped in accordance with their existence. The possession of nuclear weapon is a great responsibility, but also is a huge security threat. Although it is hard to believe that intentional nuclear war would start, there are a lot of security issues connected to the technical failures, unauthorized use of nuclear weapons, or the danger of terrorists obtaining nuclear weapons, etc., that raise anxiety about the European and global security.

Such circumstances lead to the necessity to consider the role of the EU in the context of nuclear security and assess the influence it has. The only NWS left among the members of the EU is France, and thus, the other eight NWS are not in the zone of EU impact. However, the one should not forget about the diplomatic efforts and the goal to reduce nuclear risks, which are quite in the EU scope.

One of the possible scenarios for Europe including taking part in the process on nuclear risks reduction by enhancing dialogue with other NWS via numerous channels of communication. More importantly, the EU participates in the NPT review process, which can also facilitate the process of bringing up the acute topics within the NPT framework. The case of successful role in creating the JCPOA (Joint Comprehensive Plan of Action) in 2015 illustrates the positive role the EU plays in enhancing global security.

Considering the fact that some of the EU members have launched such initiatives as the Stockholm Ministerial Meetings on Nuclear Disarmament and the Non-Proliferation Treaty and the Missile Dialogue Initiative by launched in 2019 by Sweden and Germany respectively, the EU could promote the dialogue on nuclear security within their framework, as well as encouraging other states to join the existing initiatives or launch other ones.

Another initiative to participate in is the 'Creating an Environment for Nuclear Disarmament' (CEND), which was launched by the US in 2019 and is 
focused on nuclear risk reduction specifically. Thus, despite any limitations of the EU impact, its role as a major actor in promoting and encouraging NWS to develop policies on nuclear risk reduction should not be doubted.

While critics argue that replacing the US nuclear umbrella with a French or British or German counterpart will only exacerbate the growing belief that nuclear-powered states are unable to fulfill their responsibilities, this would severely jeopardize the NPT's survival.

It is important to note that nuclear arms do not generate power automatically. They obtain power as a result of the power they are given by others (Sauer, 2020). The assumption that nuclear weapons have deterrence capabilities and are status-enhancing triggers this assumption. Critics deem nuclear weapons to be illegal and too dangerous to use. They are referring to the Nuclear Non-Proliferation Treaty, which makes nuclear weapons prohibited. It remains to be seen what impact the Treaty can have on the strategies of nuclear-armed nations and their partners.

The main question in this article was whether the EU would become yet another nuclear-armed entity, or whether it would become another regional nuclear-free zone, or whether little would change. After critically analysing each scenario, this paper contends that the outcome of this discourse will be determined primarily by which assumption wins the societal and political debate: the assumption of those who consider nuclear weapons as powerful and legitimate, or the line of reasoning of those who view nuclear weapons as too potent and thus unjustified. But, most crucially, there must be a real discussion on the subject matter.

\section{References}

Blanc, F. (2019, October 17). The European Union, a New Basis for Common Security. Green European Journal. Retrieved from https://www.greeneuropeanjournal.eu/the-european-uniona-new-basis-for-common-security/.

Brustlein, C. (2018). The Erosion of Strategic Stability and the Future of Arms Control in Europe. Institut franzais des relations internationales, IFRI Proliferation Papers, 60, November. Retrieved from https://www.noproliferation.eu/wp-content/uploads/2019/11/brustlein erosion_strategic_stability_2018_3n.pdf

Cappello, J., Hall, G., \& Lambert, S. (2002). Tactical Nuclear Weapons: Debunking the Mythology. USAF Institute For National Security Studies. Occasional Paper, 46, August. Retrieved from https://apps.dtic.mil/sti/pdfs/ADA435014.pdf

Cerulus, L. (2018). Putin: World Cup Triggered Millions of Cyberattacks on Russia. POLITICO, July 16. Retrieved from https://www.politico.eu/article/putin-world-cup-triggered-millionsof-cyberattacks-on-russia/

Cottey, A. (2014). The EU and Nuclear Non-Proliferation: Soft Power and the Bomb? Irish Studies in International Affairs, 25, 89-100. Retrieved from https://www.jstor.org/stable/10.3318/ isia.2014.25.9

Credi, O. (2019). US Non-Strategic Nuclear Weapons in Europe: Necessary or Obsolete? American Security Project. Retrieved from https://www.jstor.org/stable/resrep19821

Doug, B. (2018). Why America's Allies Should Develop Nuclear Weapons. The American Conservative. The American Conservative. Retrieved from https://www.theamericanconservative.com/ articles/why-americas-allies-should-develop-nuclear-weapons/.

Egeland, K., \& Pelopidas, B. (2020). European nuclear weapons? Zombie debates and nuclear realities. European Security, 30(2), 237-258. doi:https://doi.org/10.1080/09662839.2020.1855147 
Fedchenko, V \& Anthony, I. (2018). Nuclear Security in the Black Sea Region. Contested Spaces, National Capacities, and Multinational Potential. SIPRI Policy Paper, 49. Retrieved from https://www.sipri.org/sites/default/files/2018-12/sipripp49_nuclear_security_black_sea.pdf

Galeotti, M. (2007). A Dirty Business: Nuclear Smuggling in the Former Soviet States. Jane's Intelligence Review, 60.

Hille, K., White, E., Reed, J., \& Riordan, P. (2020). The Trump factor: Asian allies question America's reliability. Ft.com. Retrieved from https://www.ft.com/content/74576c3a-63034ba0-bbe3-15b563ce6019.

Hincu, R. (2015). EU's Policy of Disarmament as Part of its Normative Power. CES Working Papers, Alexandru Ioan Cuza University of Iasi, Centre for European Studies, Iasi, 7(2a), 472-478.

International Atomic Energy Agency. (2016). Treaty on the Non-Proliferation of Nuclear Weapons. April 22, 1970. Retrieved from https://www.iaea.org/sites/default/files/publications/ documents/infcircs/1970/infcirc140.pdf

Jurgensen, C. (2018). Europe, France, and nuclear deterrence. Revue Défense Nationale, 821(6), 56-68. Retrieved from http://www.geographie.ens.fr/IMG/pdf/europe_france_ and_nuclear_deterrence_-jurgensen.pdf

Kimball, D., \& Reif, K. (2017). Trump Questions U. S. Nuclear Policies. Arms Control Association. Armscontrol.org. Retrieved from https://www.armscontrol.org/act/2017-03/news/trumpquestions-us-nuclear-policies.

Kimball, D. G. (2019). Nuclear False Warnings and the Risk of Catastrophe. Arms Control Association. Retrieved from https://www.armscontrol.org/act/2019-12/focus/nuclear-falsewarnings-risk-catastrophe

Kristensen, H. (2010).US Nuclear Weapons Site in Europe Breached. Federation of American Scientists. 4 February. Retrieved from https:// fas.org/blogs/security/2010/02/kleinebrogel/

Kristensen, H. M. \& Korda, M. (2021). Status of World Nuclear Forces. Federation of American Scientists. Retrieved from https://fas.org/issues/nuclear-weapons/status-world-nuclear-forces/

Larose, M. (2000). MbLLER, Harold (dir.). Europe and Nuclear Disarmament. Debates and Political Attitudes in 16 European Countries. Bruxelles, European Interuniversity Press, Collection "European Policy", \#35, 1998, 311p. Études Internationales, 31(3), 590-592. Retrieved from https://www.erudit.org/fr/revues/ei/2000-v31-n3-ei3082/704200ar.pdf

Lewis, P., Williams, H., Pelopidas, B., and Aghlani, S. (2014). Too Close for Comfort: Cases of near Nuclear Use and Options for Policy. London: Chatham House.

Martin, B. E. (2016). Weapons of Mass Destruction: Nuclear Terrorism and Nuclear Proliferation. Counter Terrorist Trends and Analyses, 8(2), 17-23. Retrieved from https://www.jstor. org/stable/pdf/26369587.pdf?refreqid=excelsior \% 3Abce1140c72ce789167358dd7d68369fb

Macron, E. (2020). Speech of the President of the Republic on the Defense and Deterrence Strategy. Paris, Ecole de Guerre, 7th of February. Retrieved 28 March 2021, from https://www. elysee.fr/en/emmanuel-macron/2020/02/07/speech-of-the-president-of-the-republic-on-thedefense-and-deterrence-strategy

Müller, H., Franceschini, G., Melamud, A., Müller, D., Péczeli, A., \& Schaper, A. (2016). A nuclear-weapon-free zone in Europe: concept - problems - chances. Peace Research Institute Frankfurt. Retrieved 27 March 2021, from https://nbn-resolving.org/urn:nbn:de:0168ssoar-462142.

Nuclear Threat Initiative (NTI). (2015). The United Kingdom. Retrieved from https://www.nti. org/learn/countries/united-kingdom/nuclear/.

Nuclear Threat Initiative. (2016). Warning Bells Around Tactical Nuclear Weapons in Europe. Retrieved from https://www.nti.org/analysis/articles/warning-bells-around-tactical-nuclearweapons-europe/

Perry, W., Scowcroft, B., \& Ferguson, C. (2009a). U. S. Nuclear Weapons Policy. Council on Foreign Relations. Retrieved from https://cdn.cfr.org/sites/default/files/report_pdf/Nuclear_Weapons_TFR62.pdf.

Portela, C. (2003). The Role of the EU in the Non-Proliferation of Nuclear Weapons: The Way to Thessaloniki and Beyond. Research Collection School of Social Sciences, PRIF Reports, 65.

Quintin, A. (2020). Nuclear Weapons and Deterrence: the case of Europe. Global Risk Insights. Retrieved 19 March 2021, from https://globalriskinsights.com/2020/12/nuclear-weaponsand-deterrence-the-case-of-europe/. 
Sauer, T. (2020). Power and Nuclear Weapons: The Case of the European Union. Journal For Peace And Nuclear Disarmament, 3(1), 41-59. https://doi.org/10.1080/25751654.2020.1764260

Sechser, T. (2016). Sharing the bomb: how foreign nuclear deployments shape nonproliferation and deterrence. The Nonproliferation Review, 23(3-4), 443-458. doi: https://doi.org/10.108 0/10736700.2016.1259062

Snyder, S. A. (2015). Addressing North Korea's Nuclear Problem. Council on Foreign Relations. November 19, 2015. Retrieved from https://www.cfr.org/report/addressing-north-koreasnuclear-problem

Terhalle, M. (2017). Nuklearwaffen gegen Russland. Deutschland braucht Atomwaffen. Tagesspiegel Causa, 23 January. Retrieved from https://causa.tagesspiegel.de/politik/europa-unddie-weltweiten-krisen/deutschland-braucht-atomwaffen.html

Thränert, O. (2017). No shortcut to a European deterrent. CSS. Policy Perspectives, 5(2), 1-4. Retrieved from https://css.ethz.ch/content/dam/ethz/special-interest/gess/cis/center-forsecurities-studies/pdfs/PP5-2.pdf

Waltz, K. (1981). The Spread of Nuclear Weapons: More May Be Better: Introduction. The Adelphi Papers, 21(171), 1-10. doi: https://doi.org/10.1080/05679328108457394

Wimmer, F. (2018). European nuclear deterrence in the era of Putin and Trump - Bulletin of the Atomic Scientists. Bulletin of the Atomic Scientists. Retrieved from https://thebulletin. org/2018/01/european-nuclear-deterrence-in-the-era-of-putin-and-trump/.

\section{Список використаної літератури}

Blanc F. The European Union, a New Basis for Common Security. Green European Journal. 2019. 17 October. URL: https://www.greeneuropeanjournal.eu/the-european-union-a-new-basis-forcommon-security/ (дата звернення: 27.03.2021).

Brustlein C. The Erosion of Strategic Stability and the Future of Arms Control in Europe. Institut franzais des relations internationales, IFRI Proliferation Papers. 2018. No. 60. 74 p. URL: https://www.noproliferation.eu/wp-content/uploads/2019/11/ brustlein_erosion_strategic_stability_2018_3n.pdf (дата звернення: 27.03.2021).

Cappello J., Hall G., Lambert, S. Tactical Nuclear Weapons: Debunking the Mythology. USAF Institute For National Security Studies. Occasional Paper. 2002. No. 46. 43 p. URL: https:// apps.dtic.mil/sti/pdfs/ADA435014.pdf (дата звернення: 27.03.2021).

Cerulus L. Putin: World Cup Triggered Millions of Cyberattacks on Russia. POLITICO. 2018. July 16. URL: https://www.politico.eu/article/putin-world-cup-triggered-millions-of-cyberattacks-on-russia/ (дата звернення: 27.03.2021).

Cottey A. The EU and Nuclear Non-Proliferation: Soft Power and the Bomb? Irish Studies In International Affairs. 2014. Vol. 25. P. 89-100. URL: https://www.jstor.org/stable/10.3318/ isia.2014.25.9 (дата звернення: 27.03.2021).

Credi O. US Non-Strategic Nuclear Weapons in Europe: Necessary or Obsolete? American Security Project. 2019. URL: https://www.jstor.org/stable/resrep19821 (дата звернення: 27.03.2021).

Doug B. Why America's Allies Should Develop Nuclear Weapons. The American Conservative. 2018. URL: https://www.theamericanconservative.com/articles/why-americas-allies-shoulddevelop-nuclear-weapons/ (дата звернення: 28.03.2021).

Egeland K., Pelopidas B. European nuclear weapons? Zombie debates and nuclear realities. European Security. 2020. Vol. 30, Is. 2. Pp. 237-258. DOI: https://doi.org/10.1080/09662839. 2020.1855147

Fedchenko V., Anthony I. Nuclear Security in the Black Sea Region. Contested Spaces, National Capacities, and Multinational Potential. SIPRI Policy Paper. 2018. December. Vol. 49. 51 p. URL: https://www.sipri.org/sites/default/files/2018-12/sipripp49_nuclear_security_black_sea.pdf (дата звернення: 28.03.2021).

Galeotti M. A Dirty Business: Nuclear Smuggling in the Former Soviet states. Jane's Intelligence Review. 2007. P. 60.

Hille K., White E., Reed J., Riordan P. The Trump factor: Asian Allies Question America's Reliability. Ft.com. 2020. URL: https://www.ft.com/content/74576c3a-6303-4ba0-bbe315b563ce6019. (дата звернення: 25.03.2021). 
Hincu R. EU's Policy of Disarmament as Part of its Normative Power. CES Working Papers, Alexandru Ioan Cuza University of Iasi, Centre for European Studies. Iasi. 2015. Vol. 7, Is. 2a. P. 472-478.

International Atomic Energy Agency. Treaty on the Non-Proliferation of Nuclear Weapons. April 22, 1970. 2016. URL: https://www.iaea.org/sites/default/files/publications/documents/infcircs/1970/infcirc140.pdf (дата звернення: 25.03.2021).

Jurgensen C. Europe, France, and nuclear deterrence. Revue Défense Nationale. 2018. Vol. 821. Is. 6. P. 56-68. URL: http://www.geographie.ens.fr/IMG/pdf/europe_france_and_nuclear_ deterrence_-jurgensen.pdf (дата звернення: 28.03.2021).

Kimball D., Reif K. Trump Questions U. S. Nuclear Policies / Arms Control Association. Armscontrol.org. 2017. URL: https://www.armscontrol.org/act/2017-03/news/trump-questionsus-nuclear-policies (дата звернення: 28.03.2021).

Kimball D. G. Nuclear False Warnings and the Risk of Catastrophe / Arms Control Association. 2019. URL: https://www.armscontrol.org/act/2019-12/focus/nuclear-false-warnings-riskcatastrophe (дата звернення: 28.03.2021).

Kristensen H. S Nuclear Weapons Site in Europe Breached. Federation of American Scientists. 2010. 4 February. URL: https:// fas.org/blogs/security/2010/02/kleinebrogel/ (дата звернення: 28.03.2021).

Kristensen H. M., Korda M. Status of World Nuclear Forces / Federation of American Scientists. 2021. URL: https://fas.org/issues/nuclear-weapons/status-world-nuclear-forces/ (дата звернення: 28.03.2021).

Larose M. Müller, Harold (dir.). Europe and Nuclear Disarmament. Debates and Political Attitudes in 16 European Countries. Bruxelles, European Interuniversity Press, Collection 'European Policy', \#35, 1998, 311p. Études Internationales. 2000. Vol. 31, No. 3. P. 590592. URL: https://www.erudit.org/fr/revues/ei/2000-v31-n3-ei3082/704200ar.pdf (дата звернення: 28.03.2021).

Lewis P., Williams H., Pelopidas B., Aghlani S. Too Close for Comfort: Cases of Near Nuclear Use and Options for Policy. London: Chatham House, The Royal Institute of International Affairs, 2014. 30 p. URL: https://www.chathamhouse.org/2014/04/too-close-comfort-casesnear-nuclear-use-and-options-policy (дата звернення: 28.03.2021).

Martin B. E. Weapons of Mass Destruction: Nuclear Terrorism and Nuclear Proliferation. Counter Terrorist Trends and Analyses. 2016. Vol. 8, No. 2. P. 17-23. URL: https://www.jstor. org/stable/pdf/26369587.pdf?refreqid=excelsior \%3Abce1140c72ce789167358dd7d68369fb (дата звернення: 28.03.2021).

Macron E. Speech of the President of the Republic on the Defense and Deterrence Strategy. Paris: Ecole de Guerre, 2020. 7th of February. URL: https://www.elysee.fr/en/emmanuelmacron/2020/02/07/speech-of-the-president-of-the-republic-on-the-defense-and-deterrencestrategy (дата звернення: 28.03.2021).

Müller H., Franceschini G., Melamud A., Müller D., Péczeli A., Schaper A. A nuclear-weapon-free zone in Europe: concept - problems - chances. Peace Research Institute Frankfurt. 2016. URL: https://nbn-resolving.org/urn:nbn:de:0168-ssoar-462142 (дата звернення: 27.03.2021).

Nuclear Threat Initiative (NTI). The United Kingdom. 2015. URL: https://www.nti.org/learn/ countries/united-kingdom/nuclear/ (дата звернення: 27.03.2021).

Nuclear Threat Initiative. Warning Bells Around Tactical Nuclear Weapons in Europe. 2016. URL: https://www.nti.org/analysis/articles/warning-bells-around-tactical-nuclear-weaponseurope/ (дата звернення: 27.03.2021).

Perry W., Scowcroft B., Ferguson C. U. S. Nuclear Weapons Policy. Council on Foreign Relations. 2009 a. URL: Retrieved fromhttps://cdn.cfr.org/sites/default/files/report_pdf/Nuclear_Weapons_TFR62.pdf (дата звернення: 27.03.2021).

Portela C. The Role of the EU in the Non-Proliferation of Nuclear Weapons: The Way to Thessaloniki and Beyond. Research Collection School of Social Sciences. 2003. PRIF Reports No. 65.48 p.

Quintin A. Nuclear Weapons and Deterrence: the case of Europe. Global Risk Insights. 2020. URL: https://globalriskinsights.com/2020/12/nuclear-weapons-and-deterrence-the-case-ofeurope/ (дата звернення: 19.03.2021).

Sauer T. Power and Nuclear Weapons: The Case of the European Union. Journal For Peace And Nuclear Disarmament. 2020. Vol. 3, No. 1. P. 41-59. https://doi.org/10.1080/25751654.2 020.1764260 
Sechser T. Sharing the bomb: how foreign nuclear deployments shape nonproliferation and deterrence. The Nonproliferation Review. 2016. Vol. 23, No. 3-4. P. 443-458. DOI:https://doi.or $\mathrm{g} / 10.1080 / 10736700.2016 .1259062$

Snyder S. A. Addressing North Korea's Nuclear Problem. Council on Foreign Relations. 2015. 19 November. URL: https://www.cfr.org/report/addressing-north-koreas-nuclear-problem (дата звернення: 19.03.2021).

Terhalle M. Nuklearwaffen gegen Russland. Deutschland braucht Atomwaffen. (Nuclear weapons against Russia. Germany needs nuclear weapons). Tagesspiegel Causa. 2016. 23 January. URL: https://causa.tagesspiegel.de/politik/europa-und-die-weltweiten-krisen/deutschlandbraucht-atomwaffen.html (дата звернення: 27.03.2021) [in German].

Thränert O. No shortcut to a European deterrent. CSS. Policy Perspectives. 2017. Vol. 5, No. 2. P. 1-4. URL: https://css.ethz.ch/content/dam/ethz/special-interest/gess/cis/center-for-securities-studies/pdfs/PP5-2.pdf

Waltz K. The Spread of Nuclear Weapons: More May Be Better: Introduction. The Adelphi Papers. 1981. Vol. 21, Is. 171. P. 1-10. https://doi.org/10.1080/05679328108457394

Wimmer F. European nuclear deterrence in the era of Putin and Trump - Bulletin of the Atomic Scientists. Bulletin of the Atomic Scientists. 2018. January 8. URL: https://thebulletin. org/2018/01/european-nuclear-deterrence-in-the-era-of-putin-and-trump/ (дата звернення: 27.03.2021).

Стаття надійшла до редакцї̈ 11.04.2021

\author{
Курандо М. С. \\ кафедра міжнародних відносин ОНУ імені I. I. Мечникова \\ к. 32, Французький бул., 24/26, г. Одеса, 65058, Україна \\ Патуссі T. \\ Дублінський міський університет \\ Колінз-авеню, Уайтхолл, Дублін 9, Ірландія

\section{ЗМІЦНЕННЯ СВРОПЕЙСЬКОЇ БЕЗПЕКИ: СУЧАСНІ ВИКЛИКИ, ЯКІ СТВОРЮЄ ЯДЕРНА ЗБРОЯ}

\title{
Резюме
}

Пропозицію європеїзувати французьке стримування було озвучено президентом Франції Еммануелем Макроном у лютому 2020 року, коли він заявив, що ядерна зброя Франції, вже в міру свого існування, зміцнює європейську безпеку, а також запропонував стратегічний діалог з усіма членами Європейського Союзу щодо ролі ядерних сил Франції в європейській безпеці. Макрон підкреслив, що це питання стає все більш актуальним в даний час, коли у зв'язку з відсутністю правових норм ЄС може виявитися уразливим перед обличчям потенційної гонки озброєнь. Особливо необхідно враховувати той факт, що перспективи глобального контролю над озброєннями і зусилля з роззброєння утруднені в період зростання політичної напруженості, відродження гонки ядерних озброєнь і ослаблення довіри до багатостороннього вирішення глобальних проблем. Тому всі заходи повинні сприяти мінімізації ядерних загроз, які останнім часом є предметом світових обговорень. Усунення ядерних ризиків слід розглядати як проміжну міру зі зниження небезпеки ядерного поширення $з$ подальшою повною їх ліквідацією. Саме проаналізувавши можливі ризики, пов'язані з ядерною зброєю, та їх вплив на європейську безпеку, необхідно зосередити увагу на ролі європейських держав, що володіють ядерною зброєю (ГОЯО), їх місці в глобальній безпеці і можливих сценаріях їх майбутнього розвитку. 3 цією метою автори статті розглянули можливі перспективи становлення $\mathrm{CC}-$ як ще одного утворення, що володіє ядерною зброєю, а також ймовірність 
існування ЄС - як ще однієї регіональної без'ядерної зони і реальність змін. Основним питанням у цій статті було те, чи стане ЄС ще одним об'єктом, що має ядерну зброю, чи стане ще однією регіональною без'ядерною зоною, чи мало що зміниться. Після критичного аналізу кожного сценарію стаття стверджує, що результат цього дискурсу визначатиметься головним чином тим, яке припущення виграє суспільну та політичну дискусію: припущення тих, хто вважає ядерну зброю потужним i законним засобом, або лінія міркувань тих, хто розглядають ядерну зброю як занадто потужну i, отже, невиправдану. Але, що найважливіше, має бути справжня дискусія з цього питання.

Ключові слова: ядерна зброя, європейська безпека, нерозповсюдження, ЄС, зниження ядерних ризиків, ДНЯЗ, НАТО.

\section{Курандо М. С.}

кафедра международных отношений ОНУ имени И. И. Мечникова к. 32, Французский бул., 24/26, г. Одесса, 65058, Украина

\section{Патусси Т.}

Городской университет Дублина

Коллинз-авеню, Уайтхолл, Дублин 9, Ирландия

\section{УКРЕПЛЕНИЕ ЕВРОПЕЙСКОЙ БЕЗОПАСНОСТИ: СОВРЕМЕННЫЕ ВЫЗОВЫ, СОЗДАВАЕМЫЕ ЯДЕРНЫМ ОРУЖИЕМ}

\section{Резюме}

Предложение европеизировать французское сдерживания было озвучено президентом Франции Эммануэлем Макроном в феврале 2020 года когда он заявил, что ядерное оружие Франции, уже в силу своего существования, укрепляет европейскую безопасность, и предложил стратегический диалог со всеми членами Европейского Союза относительно роли ядерных сил Франции в европейской безопасности. Макрон подчеркнул, что этот вопрос становится всё более актуальным в настоящее время, когда, в силу отсутствия правовых норм, ЕС может оказаться уязвимыми перед лицом потенциальной гонки вооружений. Необходимо особенно учитывать тот факт, что перспективы глобального контроля над вооружениями и усилий по разоружению затруднены в период роста политической напряженности, возрождения гонки ядерных вооружений и ослабления доверия к многостороннему решению глобальных проблем. Поэтому все меры должны способствовать минимизации ядерных угроз, которые в последнее время являются предметом обсуждений в мире. Устранение ядерных рисков следует рассматривать как промежуточную меру по снижению опасностей ядерного распространения с последующей полной их ликвидацией. Именно проанализировав возможные риски, связанные с ядерным оружием, и их влияние на европейскую безопасность, необходимо сосредоточить внимание на роли европейских государств, обладающих ядерным оружием (ГОЯО), их месте в глобальной безопасности и возможных сценариях их будущего развития. С этой целью авторы статьи рассмотрели перспективы становления ЕС как ещё одного образования, обладающего ядерным оружием, вероятность существования $\mathrm{EC}$ как ещё одной региональной безъядерной зоны и реальность перемен. Главный вопрос в этой статье заключался в том, станет ли ЕС еще одним субъектом, обладающим ядерным оружием, или он станет еще одной региональной безъядерной зоной, или мало что изменится. После критического анализа каждого сценария в этой статье утверждается, что исход этого дискурса будет определяться в первую очередь тем, какое предположение победит в общественных и политических дебатах: предположение тех, кто считает ядерное оружие мощным и законным, 
или линия рассуждений тех, кто считают ядерное оружие слишком мощным и, следовательно, неоправданным. Но, что наиболее важно, должна быть настоящая дискуссия по предмету.

Ключевые слова: ядерное оружие, европейская безопасность, нераспространение, ЕС, снижение ядерных рисков, ГОЯО, НАТО. 